\title{
The Effectiveness of Islamic Input in Medical Practice (IIMP) in Improving the Knowledge, Attitude, and Practice among Medical Students in Malaysia: A 5-year Prospective Study
}

\author{
Musa $\mathbf{R}^{\mathrm{a}}$, Khoiriyah $\mathbf{U}^{\mathrm{b}}$, Mohd Arifin $\mathrm{SR}^{\mathrm{c}}$, Dzulkarnain $A A^{\mathrm{d}}$. \\ ${ }^{a}$ Department of Psychiatry, Kulliyyah of Medicine, International Islamic University Malaysia, Pahang, Malaysia \\ ${ }^{b}$ Medical Education Department, Faculty of Medicine Universitas Islam Indonesia, Yogyakarta, Indonesia. \\ ${ }^{c}$ Kulliyyah of Nursing, International Islamic University Malaysia, Pahang, Malaysia. \\ ${ }^{d}$ Kulliyyah of Allied Health Science, International Islamic University Malaysia, Pahang, Malaysia.
}

\section{ABSTRACT}

Keywords

Muslim medical student, religiosity,

effectiveness, medical program,

professionalism.

Corresponding Author

Dr. Umatul Khoirivah

Departement of Medical Education,

Faculty of Medicine, Universitas Islam

Indonesia. J1 Kaliurang Km 14.5 Sleman

Yogyakarta, 55584

Email: umakhoiriyah@uii.ac.id

Received: 30th June 2021; Accepted: 24th October 2021

Doi: https://doi.org/10.31436/imim.v21i
INTRODUCTION: In order to produce well-rounded medical doctors in the future, Islamic-based medical schools in Malaysia and other parts of the world are implementing a special approach in their curricula. The main vision of these medical schools is instillation of Islamic values in their curricula. In International Islamic University Malaysia (IIUM), a special curriculum namely Islamic Input in Medical Practice (IIMP) was introduced for this purpose. The study aim is to measure the effectiveness of this program on the aspects of knowledge, attitude and practice among our students.

MATERIALS \& METHODS: The study was conducted at The Kulliyyah of Medicine, IIUM using pre and post-test design. The population was students from intake 2010/11 $(\mathrm{n}=145)$. The data was collected through Muslim Medical Student Questionnaire (MMSQ). The first assessment was done right at the enrolment to the medical program, and the second assessment was done after five years upon completion of their course. Data was then analysed through paired t-test. RESULTS: From 145 students in initial assessment, only 102 students completed the second assessment. The remaining number were excluded due to either incomplete forms or delay the academic progress due to failure of subjects. The mean difference between pre and post shows a significant improvement in all 3 measured aspects $(p<0.001$ to 0.022$)$. CONCLUSION: The 5 -year evidence shows our IIUM program is effective to improve the knowledge, attitude and practice.

\section{INTRODUCTION}

Evidence-based practice has become a pillar practice not only in medicine, but also in education. It is more imperative when we talk about medical education. Many medical schools generally aim to produce high quality doctors; hence their curricula have to be evidence-based to best suit their vision and mission. In the recent decade, many medical schools have reformed their curricula as a response to produce competent doctors. ${ }^{1,2}$ On this note, the designed curriculum has to be evidence-based too. The curriculum needs to be tested and validate as to whether it is effective in delivering the objectives. Hence, there is a dire need to have more research and publications on the effectiveness of every implemented curriculum as an evidence-based approach. , $^{3,4}$

Many curriculum are mainly based on 3 trust aspects namely cognitive (knowledge), psychomotor (Skills) and affective (Professionalism, ethics, and jurisprudence). This is in tandem with the Malaysian Qualification Framework (MQF) as our main blueprint in shaping the Malaysian medical education. 5

A handful of medical schools have implemented the Islamic medical inputs in their medical curriculums. 
However, the methods of implementation are different between one university to another. Some scholars have evaluated the effectiveness of the Islamic curriculum in higher education but very few were conducted in the medical faculty setting.6,7 Research in medical faculty setting usually applies cross-sectional design, hence the conclusion on the outcome of the Islamic curriculum is not supported by sufficient evidence. For example, Rani et al. explored the perception of clinical students in Universiti Sains Islam Malaysia (USIM) about Muslim doctor's characteristics. The students completed a questionnaire consisting items on personality and professional characteristics of a good Muslim doctor at one time point only. ${ }^{7}$

The Kulliyyah of Medicine, International Islamic University Malaysia (IIUM) has pioneered and implemented a special module in the medical curriculum since July 1994 with the aim to produce well-rounded Muslim medical doctors. The module is called Islamic Input in Medical Practice (IIMP). The IIMP module was designed with the main focus to improve of the third component that is the affective domain. In this IIMP module, students were exposed to various aspects of a good Muslim doctor. Among the key elements of IIMP mudule are Muslim medical ethics, professionalism, leadership, managerial sciences and medical practice (Fiqh Ibadah) such as Ruksah.

The implementation of IIMP module is throughout the 5 years medical program with pedagogy approach and student-centered. The approach is rather through integrations of Islamic teachings in medical education and it is in line with the Islamization guidelines outlined by the university. 8,9 The main aim of this study is to assess the effectiveness of the IIMP program in shaping the undergraduates to be holistic and competent Muslim doctors. This is in line with the main vision of various universities in Islamic countries to equip the future doctors with fundamental Islamic knowledge related to medical issues. It is hoped, that this 5-year prospective study could provide a tangible evidence to medical curriculum development in this era.

\section{MATERIALS \& METHODS}

The study was reviewed and approved by the internal review board of International Islamic University Ethics Committee. The subjects were one cohort batch of IIUM medical students in Kuantan campus. We gathered written informed consents from our subjects prior to commencement of the data collection. This study is a 5year prospective cohort study. The subjects were everyone from one batch of medical students from IIUM intake 2010/11. The first data collection was during their first year in 2010. Demographic information was collected and the Muslim Medical Student Questionnaire (MMSQ) was the tool used. The second assessment was conducted in final year of study, 5 years later (2014) using the same forms and tools. Completed data from 102 students were analysed. The non-completed forms were excluded. Data was analyzed by using SPSS Statistics for Windows, Version 23.0 (IBM SPSS Statistics for Windows, Version 23.0. Armonk, NY: IBM Corp).

\section{Measurement Tool; Muslim Medical Student Questionnaire (MMSQ).}

In our past publication, we developed a scale to measure knowledge, attitude and practice to gauge the effectiveness of our IIMP program among IIUM students. The development of the questionnaire was described in our previous publication and the psychometric properties were good. The questionnaire was developed based on good Muslim doctor's characteristics, which was identified through the Delphi technique. Its face validity has been evaluated by conducting a pre-test of the MMSQ among medical students. Cronbach's alpha values of $0.13,0.78$ and 0.85 were obtained for Knowledge, Attitude and Practice domains, respectively. Knowledge had the poorest Cronbach's alpha value (0.13) of all 3 values. Based on Principal Component Analysis by using Varimax rotation, 3 components were extracted. Factor 1 is corresponding to 'Practice' domain, factor 2 is for 'Knowledge' and Factor 3 is for 'Attitude'. Generally, items in Practice have better factor loadings (0.37-0.79) as compared items in Attitude and Knowledge domains. ${ }^{10}$ 
The scale is named as the Muslim Medical Student Questionnaire (MMSQ). Drafting the scale was based on the Malaysian National Education Blueprint based on 3 important domains of Cognitive (knowledge), Affective (professionalism and personal development) and Psychomotor (skill). The MMSQ also has been translated in Indonesian language with proven good psychometric values in Indonesian population too. ${ }^{11}$

Among the tested areas of the MMSQ include knowledge on Maqasad Syariah, Muslim medical ethics on dealing with different gender, concept of Ruqsah and Tayammum, attitude towards medical confidentiality, effective communication, and religious practice as a Muslim doctor. The means different between the two sets of observation were analysis by using paired t-test.

\section{RESULTS}

Table 1 shows that $60.7 \%$ respondents were female. A total of 64 students obtained additional Islamic input in their previous education. From these 64 students, 37 of them obtained it during primary school and 13 of them during both primary and secondary school education.

\begin{tabular}{lccc}
\multicolumn{3}{l}{ Table 1: Socio-demographic data of the respondents } & \\
\hline Variable & N & $\begin{array}{c}\text { Percentage } \\
\text { (\%) }\end{array}$ & Total \\
\hline Gender & & & \\
$\quad$ Male & 40 & 39.3 & 102 \\
$\quad$ Female & 62 & 60.7 & \\
$\begin{array}{l}\text { Have you ever } \\
\text { received a formal Islamic }\end{array}$ & & & \\
curriculum at previous & & & \\
schools? & & 64.0 & \\
$\quad$ Yes & 64 & 36.0 & \\
$\quad$ No & 36 & & \\
If the answer is yes, which & & & \\
school is the respondent & & & \\
received the Islamic & & & \\
curriculum? & & 21.9 & \\
$\quad$ Primary school & 37 & 20.3 & \\
$\quad$ Secondary school & 14 & & \\
$\quad$ Both & 13 &
\end{tabular}

Table 2 shows the comparison of total scores of Knowledge, Attitude and Practice domains between first assessment (start of Year 1) and second assessment (end of Year 5). From Table 2, the paired $\mathrm{p}$ values were significant in all three domains. The mean scores for first assessment were lower compared to the second assessment. This indicates that students were better in 3 domains towards the end of their academic training.

\begin{tabular}{|c|c|c|c|c|c|c|}
\hline \multirow[t]{2}{*}{ Variable } & \multicolumn{2}{|l|}{ Mean } & \multicolumn{2}{|c|}{$\begin{array}{l}95 \% \\
\text { Confidence } \\
\text { Interval }\end{array}$} & \multirow[t]{2}{*}{$\begin{array}{l}\text { Standard } \\
\text { Deviation }\end{array}$} & \multirow[t]{2}{*}{ P value } \\
\hline & $\begin{array}{l}\text { Pre } \\
\text { Year } 1\end{array}$ & $\begin{array}{l}\text { Post } \\
\text { Year } 5\end{array}$ & lower & upper & & \\
\hline Knowledge & 35.15 & 37.54 & -3.332 & -1.452 & 4.785 & $* * 0.001$ \\
\hline Attitude & 19.44 & 20.13 & .099 & 1.273 & 2.988 & $* 0.022$ \\
\hline Practice & 34.03 & 36.86 & -4.662 & -1.005 & 9.309 & $* * 0.003$ \\
\hline
\end{tabular}

*Significant $\mathrm{p}$ values (paired t-test)

\section{Discussion}

Malaysia has made significant move towards the improvement of all tertiary curricula by establishing Malaysia's Higher Education Blueprint 2015-2025 in 2013. Based on this blueprint, one of the main focus is on the aspect of personal development. The blueprint clearly stated that the curriculum should highlight holistic education based on six 'Student Aspirations'. The main vision is, education in Malaysia should mold the students on the aspects of ethics and morality (Akblak), knowledge (Ilmu) and skills. ${ }^{5}$

Taking into consideration that in an ideal situation, Muslim patients require unique medical treatment approach which is in line with their Islamic faith. Hence, a special medical curriculum needs to be designed to fulfill this aspiration. ${ }^{12}$ Curriculum design in medical education has been an area of interest and became a topic of debate especially on the issue of the most effective approach. An effective curriculum needs to be designed to facilitate the acquisition of knowledge, skills and more importantly the personal development of our future Muslim doctors. The medical curriculum should reflect this importance of shifting trend toward evidence-based. ${ }^{13}$

Having said that, there has been an effort to imbue the Islamic module into medical curriculum from a few medical schools around the world. Islamic medicine has a long history of establishment since the Golden Age of Islamic Medicine (in 638 AD). ${ }^{14}$ However, the publications related to the effectiveness of Islamic curriculum is scarce. This is because the research conducted in this area is not many. On a positive side, we are beginning to see some movement in data collection and analysis of the effectiveness of IIMP. ${ }^{15,16}$ 
From our study, the respondents demonstrated upward progression on all 3 tested elements, namely knowledge, practice and attitude. The findings are almost similar to a research done by Rani et al which was conducted by another public university in Malaysia; Universiti Sains Islam Malaysia (USIM). The university is founded with the main trust of Islamic integration. They managed to prove that the clinical students seemed to benefit from the Islamic-integrated medical curriculum. They found that the senior clinical students had better insight on desirable personal and professional characteristics of good future Muslim doctors. ${ }^{7}$

During the establishment of Islamic curriculum in IIUM by the main founder; Prof Dr Omar Kasule, the main objective of the curriculum was to recognize Islamic issues related to each medical discipline according to Islamic frame-work. The ultimate aim was to create a new creative thinking that could facilitate them make original contributions to the discipline from the Islamic perspective. ${ }^{17}$

There is an awareness on the need for Muslim doctors and Muslim undergraduates to be specially trained on the Muslim medial curriculum. This with the hope that in the future they will be able to conceptualize the Islamic medical approach to deliver the best treatment to their Muslim patients and research. ${ }^{15}$ Medicine and revelation should be the main basis in designing the objective of Islamic medical training. With this approach, the students or future doctors would be able to recognize their creator and strengthening their faith (Iman). ${ }^{16}$ Many scholars believe that it is imperative for the future Muslim health professionals to have a solid foundation in the aspects of Islamic beliefs, values, morals and practices. ${ }^{18}$ Interestingly these 3 mentioned elements are well highlighted and measured in our MMSQ scale.

We admit here that it was rather difficult to make a comparison on the effectiveness of Islamic medical curriculum between different universities as there are not many published articles related to this topic. However, the Islamic integrated curriculum has been proven effective in other fields mainly on education of non-medical fields. ${ }^{19-21}$
The strength of this study is the design which is prospective 5-year follow up. With this methodology, we could confidently say that our undergraduates were shaped accordingly by the curriculum. However, to say the students' improvement is directly caused by IIMP, we have to be careful. Despite having the advantage of 5 years cohort study, we also identified a few limitations. Sample size of this study is low. The total number of students analyzed was 102 out of 142 which contribute to $72 \%$ rate. It is recommended to conduct the study in various contexts with a larger sample size. Mix method design is also suggested to capture a more comprehensive picture to evaluate the effectiveness of implementing Islamic curriculum in medical faculties.

\section{CONCLUSION}

The current evidence shows that the IIMP which has been implemented in IIUM is effective in shaping our undergraduates at least to be a better person if not better doctors. The IIMP has directed the education process in IIUM based on Islamic values. The IIMP has also assisted students to enhance the knowledge, skill and attitude required to be a good Muslim doctor.

\section{CONFLICT OF INTEREST}

Nil and the study was not funded by any grant.

\section{REFERENCES}

1. Bleakley A, Brice J, Bligh J. Thinking the post-colonial in medical education. Medical Education. 2008;42 (3):266-270.

2. Andersen S, Stentoft D, Emmersen J, Rasmussen S, Birkelund S, Nøhr SJi. Contention over undergraduate medical curriculum content. Int J Med Educ. 2019;10:230-1

3. GMC. Tomorrow's Doctors: Recommendations on Undergraduate Medical Education. General Medical Council. London. 1993.

4. Watmough S, Taylor DC, Garden A, Ryland I. Educational supervisors' views on the competencies of preregistration house officers. Br J Hosp Med (Lond). 2006;67(2):92-5. 
5. Ennew C. Malaysia's Higher Education Blueprint 2015-2025-the Implementation Challenge. The Observatory on Borderless Higher Education. 2015 Available; https://www.kooperationinternational.de/uploads/ media/3.Malaysia_Education_Blueprint_2015-2025 Higher Education .pdf

6. Sukirman. The curriculum evaluation of islamic education study program of tarbiyah and teaching sciences Faculty of State Islamic University of Raden Fatah Palembang. Journal of Islamic Educa tion .2018;23(1): 87-104

7. Rani MDM, Jamaludin J, Azmi AN, et al. Perception of Medical Professionalism among Clinical Students at Universiti Sains Islam Malaysia. Journal of Medicine. 2017;18(2):56-61.

8. Shahar MA, Idris MF, Mohamad CAC, Razali ZA. The Formulation of Classification for Islamization in Medicine: Review on 15 Years of Publications from Kulliyyah of Medicine. IUM Medical Journal Malaysia. 2018;17.43-8

9. Osman AJJoE, Sciences S. Islamic input in medical program: a realization of a holistic medical education. Journal of Education and Social Sciences. 2016; 4. 147-53.

10. Musa R, Rani M, Che A, Draman S. Development and Validation of a new Multidimensional Questionnaire called Muslim Medical Student Questionnaire (MMSQ) among Malaysian Undergraduates. IIUM Medical Journal Malaysia. 2018;17 (2).97-106

11. Khoiriyah U, Wijaya D, Musa R. Adaptation and Validation of the Muslim Medical Students Questionnaire (MMSQ) in the Indonesian Language. IIUM Medical Journal Malaysia. 2021;20(2).119- 25

12. Haq H, Khan RA, Yasmin RJPjoms. Healthcare needs of the Muslim patient community in the undergraduate medical curriculum-Are we there? Pak J Med Sci. 2019;35(3):836-41.

13. Nunan D, Jackson R, Heneghan C. What next for education in evidence-based healthcare? A call for submissions. BMJ. 2020;25:41-3. doi:10.1136/ bmjebm-2019-111301.

14. Pocock L, Rezaeian M. Medical Education and the
Practice of Medicine in the Muslim countries of the Middle East. Middle East Journal Of Family Medicine. 2016; 14(7):28-38

15. Jamilah J, Dzulkhairi M, Ariff H, Nasri Isnail, NM. Integration of Islamic input in medical curriculumUniversiti Sains Islam Malaysia (USIM) experience. IIUM Medical Journal Malaysia. 2014;13(2).73-7

16. Momtaz YA, Hamid TA, Yahaya NJRJoMS. The role of religiosity on relationship between chronic health problems and psychological well-being among Malay Muslim older persons. Research Journal of Medical Sciences. 2009;3(6):188-193.

17. Kasule OH, Ethics P. A 13-years Experience of Integrating Islamic Values in the Medical Curriculum In South-East Asia. 2009.

18. Zainuddin ZI. Integration of Islamic Perspectives into Medical Imaging Curriculum: an Outcome Based Education Approach. IIUM Medical Journal Malaysia .2018;17(1).23-30

19. Lubis MA, Yunus MM, Ishak NM, Muhamad TA, Diao M. The effectiveness of strategies and techniques in teaching and learning Islamic education. Paper presented at: International Conference on Education and Educational Technologies-Proceedings. 2010.

20. Lubis MAJGJA-T. Effective implementation of the integrated Islamic education. Global Journal AlThaqafah. 2015;5(1):59-68.

21. Lubis MA, Yunus MM, Embi MA, Sulaiman S, Mahamod Z. Systematic steps in teaching and learning Islamic education in the classroom. Procedia - Social and Behavioral Sciences. 2010;7:665-670. 